\title{
The effect of advanced industry on the resilience of the economy during war - the Israeli hi-tech industry as a case study
}

\author{
Erez Cohen \\ Ariel University \\ Israel \\ erez@ariel.ac.il
}

\begin{abstract}
The effect of war on domestic economic indicators has been repeatedly explored in many countries and regarding different eras. The current study focuses on the Israeli economy during the Second Lebanon War, which erupted in 2006, and shows the contribution of Israel's advanced industry to the resilience of the local economy during that period. This resilience is clearly manifested in the Gross Domestic Product (GDP) indicator, which continued to grow at an increasing rate despite the war and unlike previous wartime eras experienced by Israel .The explanation of the change in the behavior of the GDP during the Second Lebanon War versus its behavior during previous wars is rooted in the striking technological transformation experienced by the Israeli economy from the mid-1990s until the onset of this war. The transformation resulted from the rapid and consistent development of Israel's advanced industry, with its high recognized contribution to the Israeli economy's total GDP, both in absolute terms and relative to other industries. The paper presents data attesting to this contribution and portraying its high probability.
\end{abstract} $8330.2014 / 7-2 / 1$

Keywords: War, Israeli Advanced Industry, Israel Economy, Resilience of the Economy.

JEL classification: N45, O33. Introduction

\section{INTRODUCTION}

The research literature includes many publications indicating the relationship between war and various economic indicators and portraying the various factors affecting this relationship ${ }^{1}$ (Collier, 1999; Yang $\&$ Lester, 1994; Stubbs, 1999; Lee, 1997, and more). The current study brings evidence of another factor affecting the economic resilience of a country at war, which helps it cope with the damages inflicted by war and moderates the negative consequences of war for the economic indicators. The research claim is that an economy with a stronger and more developed advanced industry will show greater stability and resilience in the face of economic damages inflicted by war. The study focuses on the Israeli economy since, on the one

\footnotetext{
Such as the extent of government expenditures on defense, the duration and extent of the war, the scope of physical and infrastructure damages caused as a result, the economy's interest rate environment, the exchange rate, etc.
} 
hand, Israel has been involved in a relatively large number of wars and security crises, and on the other, it has a particularly developed advanced industry.

The academic literature includes many dated and more recent studies examining the effects of war on the local economy throughout history. Some have examined this effect in ancient Greece (Rawlings, 2007), some the effect of World War II on the economy of Germany (Kaldor, 1946, Overy, 1994), and others the effect of past wars on other strong economies worldwide, such as Britain (Hancock, 1949), Japan (Bloch, 1941; Pauer, 2002), and others.

Some have claimed that war has a direct and immediate harmful effect on domestic economic indicators, since the belligerence paralyzes or at least moderates overall consumer activity (as citizens are in a state of anxiety and stress and are not eager to visit shopping centers and entertainment complexes). The diminishing of consumer activity has a direct effect on production in the economy and leads to its reduction. The decrease in the economy's production has a moderating effect on foreign trade and reduces domestic exports. Moreover, an economy at war is less attractive to foreign investors and therefore foreign investments decrease. Circumstances involving lower indicators of private consumption, export, and foreign investment might naturally lead to a drop in the Gross Domestic Product (GDP) composed of these indicators. One study that makes this claim is that conducted by Collier (1999), examining the effect of civil war on the economy. In this article, the author suggests simple theoretical frameworks for exploring the effects of war on the local economy, examined in times of war and subsequently. In his conclusion, the author states that war in general, and civil war in particular, is a destructive phenomenon with a negative effect on the level and composition of economic activity and that it is particularly damaging for the country's capital stock. This as a result of the devastation inflicted, investors' unwillingness to invest in a country immersed in a security crisis, and due to capital flight.

In contrast, others claim that war appears to be associated with extensive military spending, leads to a rise in public expenditures (a GDP indicator), and offsets the drop in the other GDP indicators, thus creating a positive effect on the country's total GDP. These studies are supported by the economic data of countries at the time they were involved in wars and subsequently, clearly indicating the positive effect of the conflict and fighting period on the economic indicators of these countries and mainly on the GDP and unemployment indicators (Yang \& Lester, 1994). A good example of this is the jump in the US GDP during 1941-1945 (World War II), the most significant increase in this index in such a short period in the entire economic history of the United States. Moreover, the sharp drop in the US unemployment rate ${ }^{2}$ upon the conclusion of World War II in 1945 strengthens this conviction of the positive implications of the war for this index. Another study (Stubbs, 1999), which also indicates the positive effect of war on the country's economy, portrays the existing association between wars and the massive capital infusion by foreign countries and private investors upon their conclusion, contributing to the country's economic development. This contrast, as presented in the studies cited above, stresses the conflict between the positive and negative effects of war on the country's economy.

In this context, the report of the Institute for Economics and Peace ${ }^{3}$ (2011), which provides details of the positive and negative effects of five wars and states of conflict on US economic indicators over a period of some 70 years, ${ }^{4}$ is noteworthy. On one hand, these five wars ${ }^{5}$ led to an increase in government military

2 In 1945 the US unemployment rate was only $1.9 \%$.

3 The Institute for Economics \& Peace (IEP) has offices in Sydney, New York, and Washington, D.C. It works with a wide range of partners internationally and collaborates with intergovernmental organizations on measuring and communicating the economic value of peace.

4 From the beginning of World War II in 1941 until the years of conflict in Afghanistan and Iraq during 2005-2013.

5 World War II, the Korea War, the Vietnam War, the Cold War, and the Wars in Afghanistan and in Iraq. 
spending. This policy of increasing government expenditures in times of war has positive effects on the economy as it constitutes an important source leading to increased demands and employment within the economy and has a real effect on the development of new technologies and the generation of new industries. Moreover, even if this expenditure is covered by progressive taxes, it contributes to increased efficiency of the distribution of revenues in the economy. On the other hand, such unplanned increased government expenditures have negative effects as well, as evident in the US economy during the period from World War II until the end of the first decade of the 2000s. Government military spending led to a significant increase in the US deficit during World War II from 1941-1945 (Lee, 1997), during the Cold War against the Soviet Union from the late 1970s to the mid-1980s (Higgs, 2006), and also during the years of fighting in Afghanistan and Iraq throughout 2003-2010 (Baker, 2007; Stiglitz \& Blimes, 2011).

In contrast, government military spending during the Korea War was compensated for by tax hikes and by an increased tax burden on citizens (Ohanian, 1997), while during the Vietnam War, increased military spending was manifested in a rise in inflation pressures within the American economy (Riddell, 1970). Thus, the claim that increased military spending is good for the economy is not necessarily true in most standard economic models.

Baker's study attempts to portray a real evaluation of the economic effect of increased military spending on the US economy during the wars in Iraq and Afghanistan (Baker, 2007). The research findings, published by the Center for Economic and Policy Research (CEPR), ${ }^{6}$ contend that the increase in military spending has a positive effect on two primary economic indicators: the real GDP and the employment market. The main novelty of the current study, however, is its statement that the positive effect of increased military spending on these two economic indicators lasts for only 5 years, whereupon they show a real drop (compared to a parallel model of the same rate of increased government expenditures ${ }^{7}$ for other needs). Then again, the research findings show that increased military spending has an immediate negative effect on other economic indicators such as industrial production, export, and others. ${ }^{8}$ In addition to these studies, Edelstein's treatise, which presents details of the direct and indirect costs of war for the US economy in the twentieth century, is also noteworthy (Edelstein, 2000). In addition to the studies cited, which focus on the US economy, many other studies explore the effect of wars on various European economies and reach the same unequivocal conclusion regarding the ambivalent association between increased government military spending and the various economic indicators (Warren, 1940; Bosken \& Lawrence, 1990; Castles, 1999). Hence, the research literature seems to encompass many publications on the effect of war on the economy, but nonetheless it is still not possible to unequivocally determine the direction of the effect, its strength, and the time range of this impact on the economic indicators.

\section{ECONOMY AND WAR - THE CASE OF ISRAEL}

The current study focuses on the economy of Israel, a country with relatively frequent states of conflict and fighting compared to others. Many studies have explored the Israeli economy in general and the effect of the country's wars in particular on the local economy and industry (Bard, 2007; Ben-Bassat, 2002; Lebrecht, 2003; Karsh, 2002; Neuman \& Shenhav, 1977, and others). Some indicated a clear association between the state of war and several tendencies of the local economy, such as increased government military spending, ${ }^{9}$

6 Center for Economic and Policy Research.

About $1 \%$ of the GDP.

8 See: Baker (2007), Table 1, p. 6.

Sometimes manifested in increasing the deficit, tax hikes, and increased rates of inflation. 
the state's diminished revenues ${ }^{10}$ damages to the tourism industry, and drops in the local stock market. This part of the article shall begin with an examination of the effect of war on the GDP and unemployment indicators in the Israeli economy, as follows:

The Six Day War broke out in 1967 after a year of deep economic recession in Israel. The total GDP was already in decline as early as $1966,{ }^{11}$ with a significant rise in unemployment rates. ${ }^{12}$ As a result, increased public expenditures during the war, which demanded massive military recruitment of workers, did not cost the Israeli economy a thing, as it was not necessary to divert production factors (workers) from other industries to those required by an economy at war and, in actual fact, only those who if not for the war would have remained unemployed were used for defense purposes. The general military recruitment undertaken for purposes of the war did indeed disrupt some manufacturing industries, which were compelled to manage with depleted human resources, however this cost was fairly low. In conclusion, the Six Day War ultimately contributed to the Israeli economy and helped extricate it from the worsening recession in the year prior to the war. The war resulted in an immediate rise in local demand for goods and services, assisted by the large available supply of manufacturing factors who were unemployed during the recession that preceded the war, leading to considerable diminishing of unemployment rates. This statement is not true, however, of the other wars encountered by the Israeli economy, as in these wars employment was at normal levels and therefore the utilization of manufacturing factors for the war effort demanded of the economy significant concessions in various production industries, with an immediate detrimental effect on the total GDP and no real contribution to employment. Moreover, due to Israel's considerable victory in the Six Day War the Israeli public was left with a clear sense of euphoria and optimism, manifested in increased private consumption and investments and leading to rapid growth of the Israeli GDP by the end of the decade, but this did not happen after the other wars. Figures 1 and 2 below present the changes in the GDP and in unemployment indicators within the Israeli economy from 1960 to 2013.

Throughout this lengthy period, Israeli society and the Israeli economy experienced many security conflicts, however only several of these were designated "wars" and most were considered "military operations". Here we must distinguish between the terms "war" and "military operation", as the definition of a short (such as the Six Day War) or lengthy (such as the First Lebanon War) military operation as a "war" has direct implications for the government's budget, since a war requires extensive compensation of all citizens harmed by the military activities, whether directly or indirectly, and defining an operation as a "war" also means that the government must take immediate action to adjust and change its budget accordingly. The following analysis shall refer only to those periods of fighting defined by the State of Israel as wars and not to the military operations undertaken by Israel during the period under investigation.

The research methodology based on analyzing the Israeli economy indices during the wars periods has been examined in this research, such as presented in the following figures.

Figure 1 below presents, as stated, the changes in the total GDP of the Israeli economy during the different war periods in Israel from the 1960s to the present. During this period the State of Israel was involved in five wars, as follows: In (June) 1967 the Six Day War, ${ }^{13}$ in (April) 1969 until (August) 1970 a separate campaign known as the War of Attrition, and in (October) 1973 the Yom Kippur War. The First Lebanon War began twenty years after the Yom Kippur War, in June 1982 (and continued for about three years until

10 Deriving mainly from the drop in taxes collected as a result of economic paralysis.

11 In 1966 the product decreased by $0.1 \%$, after a growth of $9.1 \%$ in 1965 .

12 In 1965 the unemployment rate was only 3.6\%, however in 1966 and 1967 the unemployment rate rose to $7.4 \%$ and $10.4 \%$ (respectively).

13 This war was indeed a short war but it was very significant for Israeli society in many respects. 
June 1985) and the Second Lebanon War, the last war included in the current analysis, began in July 2006 and lasted about a month and a half. As stated, Figure 1 presents the changes in Israel's total GDP from 1960 to 2003.

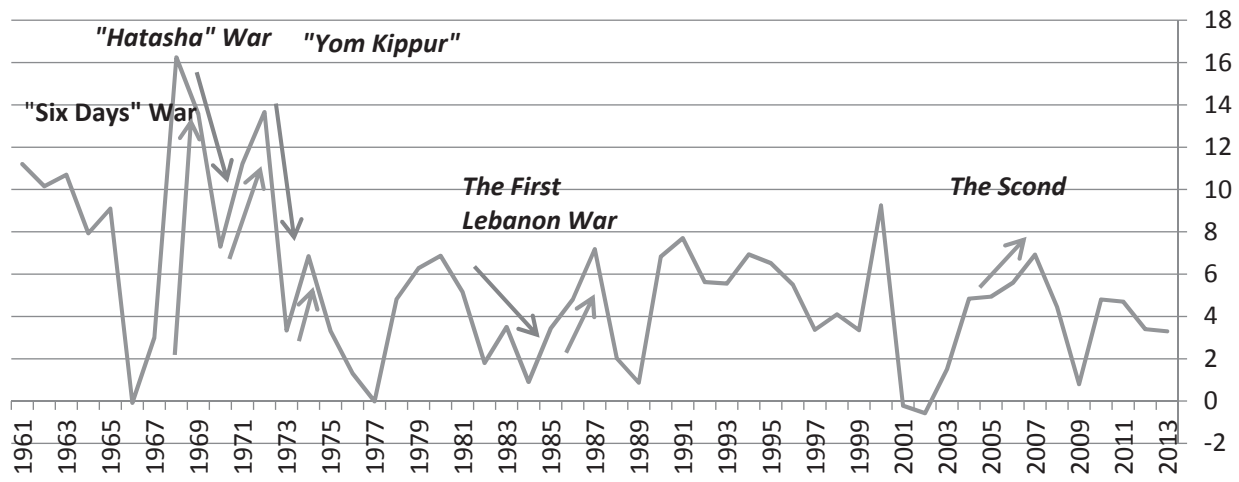

Figure 1: Israel's total GDP during the years 1960-2013 (annual \%) ${ }^{14}$

The data in Figure 1 mostly confirms the immediate negative effect of war on the total GDP in times of war, as in three of the five war periods surveyed (the War of Attrition, ${ }^{15}$ the Yom Kippur War, ${ }^{16}$ and the First Lebanon War ${ }^{17}$ ) GDP growth was relatively moderate compared to previous years. In contrast, the drop in GDP growth during the Six Day War (in 1967) commenced, as stated, as early as one year before the war began (reaching a slight decline), ${ }^{18}$ while the Second Lebanon War (in 2006) had a negligible effect on the Israeli economy (Gabbay, 2009) and the GDP continued to grow at an increased rate even during the war itself. ${ }^{19}$ The explanation for the improvement in GDP growth indicators during the Six Day War in 1967 was presented above and will not be repeated, while the explanation for GDP growth in 2006, during the Second Lebanon War, shall be presented below, supporting the basic claim of the current document.

In addition to the immediate negative effect of the war on the GDP, the data in Figure 1 above also indicates another contrasting and not less interesting trend, i.e., the prominent increase (sometimes even jump) in GDP growth in the years immediately following the war's conclusion. This trend was evident in all five war periods examined in Figure 1, with the most conspicuous being the years subsequent to the Six Day $\mathrm{War}^{20}$ and the War of Attrition. ${ }^{21}$ This arouses, once again, the question of the war's real effect on the

14 Source: Central Bureau of Statistics, Israel.

15 In 1968, the year before the War of Attrition, the gross domestic product grew at a rate of $16.24 \%$, while in the years of the war, 1969 and 1970, the product grew at a more moderate rate of $13.56 \%$ and $7.3 \%$ (respectively).

16 In 1972, the year before the Yom Kippur War, the GDP grew at a rate of $13.66 \%$ while in the year of the war, 1973, the GDP growth was only $3.4 \%$.

17 In 1981, the year before the Second Lebanon War, the GDP grew at a rate of 5.15\%, while during the years of the war, 1982-1984, the GDP grew at a moderate rate of $1.8 \%, 3.5 \%$, and $0.9 \%$ (respectively).

18 In 1966, the year before the Six Day War, the GDP showed no growth and even diminished slightly $(-0.08 \%)$, while in the year of the war, 1967, it began to grow at a moderate pace (3\%).

19 In the year of the Second Lebanon War (2006) the GDP grew at a rate of 5.6\%. This is slightly higher than the GDP growth in the year before the war (4.94\%).

20 In 1968, the year after the Six Day War, the GDP increased by a sharp rate of $16.24 \%$ !

${ }_{21}$ In 1971, the year after the War of Attrition, the GDP jumped by a sharp rate of 11.22 ! 
economy's growth. This since the immediate drop in the GDP indicator during the war was completely obliterated in the post-war years when the economy experienced rapid and renewed growth for a period of normally more than one year, offsetting the economy's losses accruing to the war. This question as to the effect of the war on the economic indicators is enhanced in view of changes in the Israeli employment market during these periods, as presented in Figure 2.

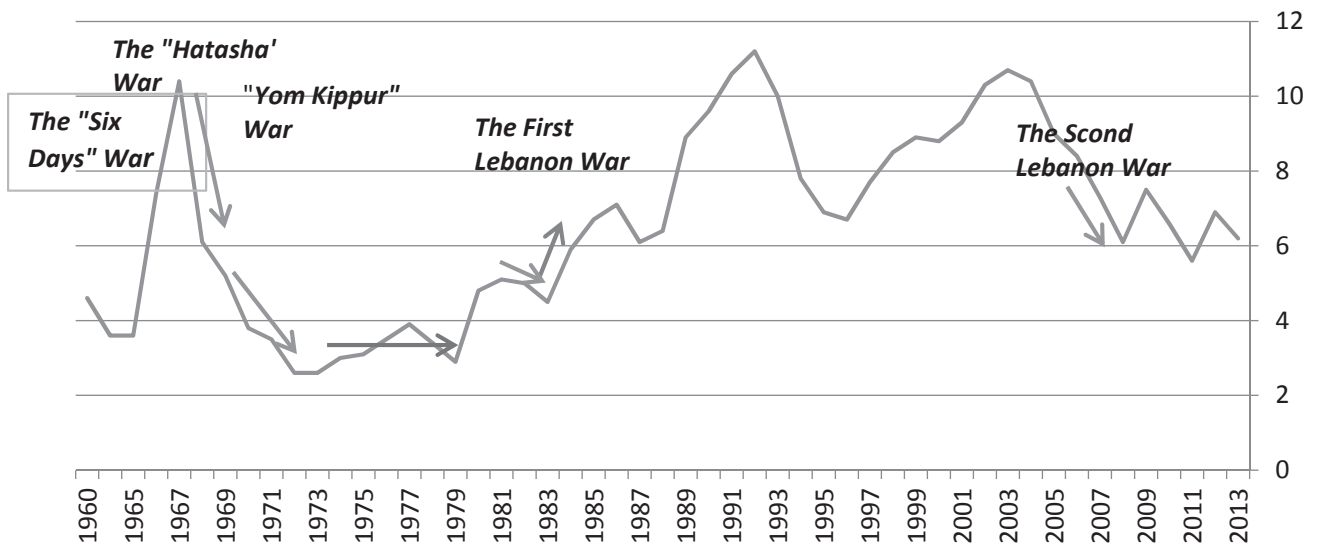

Figure 2: Total unemployment index of the Israeli economy during the years 1960-2013 22

The data in Figure 2 shows that during most of Israel's wars the unemployment rate diminished, and in fact from the Six Day War (1967) to the Yom Kippur War (1973) unemployment in Israel dropped consistently from $10.4 \%$ in 1967 to a minimal rate of only $2.6 \%$ in 1973 . This shows that the three wars experienced by Israeli society in this short period positively contributed to or at least had no negative effect on Israel's total unemployment rate. In contrast to this clear trend, during the First Lebanon War (19821985) no apparent inclination was evident in this index, as Israel's rate of unemployment showed moderate fluctuations, ${ }^{23}$ while during the Second Lebanon War (2006) the drop in unemployment ${ }^{24}$ that had begun several years earlier continued. Similar to the explanation of GDP data, this trend of improvement in the unemployment index during the Second Lebanon War will also be explained further on in this document in support of its thesis.

Hence, it seems that the data concerning the Israeli economy during the period studied, as presented so far, provides answers as to the effects of the war on two of the economic indicators examined. The data in Figure 1 attests to a drop in the GDP immediately preceding the war and a rise in the GDP in the post-war years, while Figure 2 indicates a general trend consisting of a diminished unemployment rate, or at least no increase, during the war years. This indeed does not prove a positive causal relationship between wars and

22 Table No. 12.1: Labor Force Surveys. Source: Central Bureau of Statistics, Israel.

23 In 1982, when the war broke out, the unemployment rate was 5\%, in 1983 it diminished slightly and reached $4.5 \%$, and in 1984 it rose to $5.9 \%$.

24 The drop in unemployment began as early as 2003 (10.7\%), with lower unemployment rates in 2004 and 2005 (10.4\% and $9 \%$, respectively), and in 2006 (Second Lebanon War) the rates continued to drop (8.4\%), with this trend continuing for another two years in 2007 and 2008 ( $7.3 \%$ and $6.1 \%$, respectively). 
increased GDP or an improvement in the rate of employment, however it serves to refute claims of the alleged negative effect of wars on these important indicators.

Despite the possible interest aroused by this data, it does not seem to constitute any real novelty or to expand current knowledge and claims on the effect of wars on economic indicators (GDP and unemployment). Thus, the novelty of the current study is in identifying an intervening factor in the relationship between wars and domestic economic indicators. The study assumes that Israel's advanced industry (i.e., its hi-tech industry) constitutes an intervening variable affecting the direction and strength of the association between wars and Israel's GDP and unemployment indicators. This premise, to be detailed below, attributes a critical role to Israel's advanced industry that emerged in the 1990s, in moderating the effect of wars on the GDP and unemployment indicators.

\section{THE IMPACT OF ISRAEL'S ADVANCED INDUSTRY ON DOMESTIC ECONOMIC GROWTH}

As stated, the State of Israeli is coping with security instability and with a continuous conflict with its neighbors, however its strength and ability to survive in this intimidating reality depends not only on its military might rather possibly also on its economic forces, deriving from the quality of its citizens' human capital as manifested in the development of advanced industry.

The thesis of the current study claims, as stated, that advanced industry has a considerable effect on the resilience and stability of the local economy in times of war. This claim (to be justified below) is based on the belief that advanced industry has a positive effect on domestic economic indicators in times of peace and routine as well. These claims obviously require explanation and supporting evidence, which will be provided forthwith:

Israel's advanced industry has been subjected to productive research, examining its rapid development and its endurance in face of external stressors such as the global financial crises of the 2000s. Since the late 1980s, the Israeli hi-tech industry has shown unprecedented growth. The Information and Communication Technology (ICT) sector in particular has exhibited innovative qualities and attained a leading position worldwide. In spite of its small size, Israel is considered a global leader in this industry. Various studies have attempted to analyze the story of the Israeli hi-tech industry and its trajectory to success. Most of them have focused on the processes and conditions that led to an agglomeration of resources and infrastructure and the formation of a unique hi-tech sector (Avnimelech \& Teubal, 2004; Breznitz, 2006; De Fontenay \& Carmel, 2001; Bard, 2007). Others reveal the environmental and organizational processes and the critical paths that underline the evolution, structure, and comparative advantage of Israel's hi-tech industry (Senor \& Singler, 2012).

This paper supports the claim of the crucial role of Israel's hi-tech industry in its economy (particularly in times of war). This industry is one of the backbones of the Israeli economy and it is considered one of the main contributors to the growth of the economy, employment, and GDP, constituting a primary source of foreign currency and government revenue from taxes. The Israeli hi-tech industry is global by nature ${ }^{25}$ and therefore its contribution to Israel's total exports is very significant, providing a major boost to the country's economic expansion (Cohen, 2009).

The Israeli hi-tech industry is considered a very advanced industry, both in absolute terms and compared to other industries in the Israeli economy. This industry is at the forefront of global technological

25 Since a large part of its products are characterized by innovative information, enabling the development of advanced products and quality services, and are very easily transferred between countries. 
knowledge and it has had a large impact on increasing foreign and local private investments in the Israeli economy. The phenomenal growth of the industry throughout the 1990s significantly increased Israeli exports, raising the average pay and the number of employees and consequently contributing to a rise in economic productivity and outcomes.

In the 1990s the hi-tech industry became the main driving force of Israel's economic growth, thanks to the venture capital industry that emerged early in the decade and expanded within the Israeli economy at an unprecedented rate. The emergence of this industry in the Israeli economy heralded a new prosperous era of technological initiative and innovation in Israel's hi-tech industry. This era was characterized by the establishment of independent firms that competed in the global market and attracted foreign investors, whether directly or through venture capital funds. This led to emergence of the venture capital industry, fueling hi-tech companies in general and startup companies in particular.

In order to illustrate the contribution of the local advanced industry to the Israeli economy, Figures 3-6 below shall examine the increase in the number of those employed, in the GDP, and in the exports of Israel's advanced industries, from the mid-1990s until 2013, versus changes in total Israeli export and GDP indicators during those years. The development of Israel's advanced industry has accelerated considerably from the mid-1990s until the present, to a large degree thanks to the large incoming wave of immigrants from the Commonwealth of Independent States, which included technologically educated immigrants. In this period, a significant rise was evident in the number of jobs in this industry, as shown in Figure 3 below:

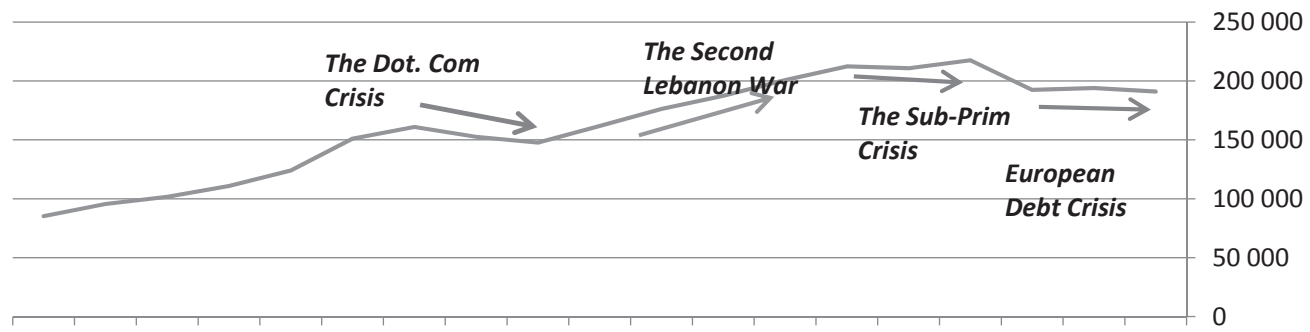

1995199619971998199920002001200220032004200520062007200820092010201120122013

Employed People in Israel ICT Industry

Figure 3: Total employment in the Israeli ICT sector, 1995-2013 (Thousands) ${ }^{26}$

The data in this figure attests to the increase in the number of those employed in Israel's advanced industry since the mid-1990s, with a drop in the number of employed during global financial crises (the dotcom crisis) or at least no increase (during the subprime crisis and the European debt crisis). In addition, the accelerated growth in the number of those employed in this industry during the second half of the 2000s, including 2006 when the Second Lebanon War took place, as stated, is particularly conspicuous.

Concurrently with the significant increase in the number of those employed in Israel's advanced industry during the past two decades, the average GDP per job in the advanced industry also began to increase, greatly exceeding the average GDP per job in Israel's total industry, and thus contributing to the total increase in Israel's GDP. The data in the figure below presents the increase in the GDP per worker in Israel's advanced industry during the ten years preceding the Second Lebanon War and until 2006, the year of the war.

26 Source: Israeli Central Bureau of Statistics. 


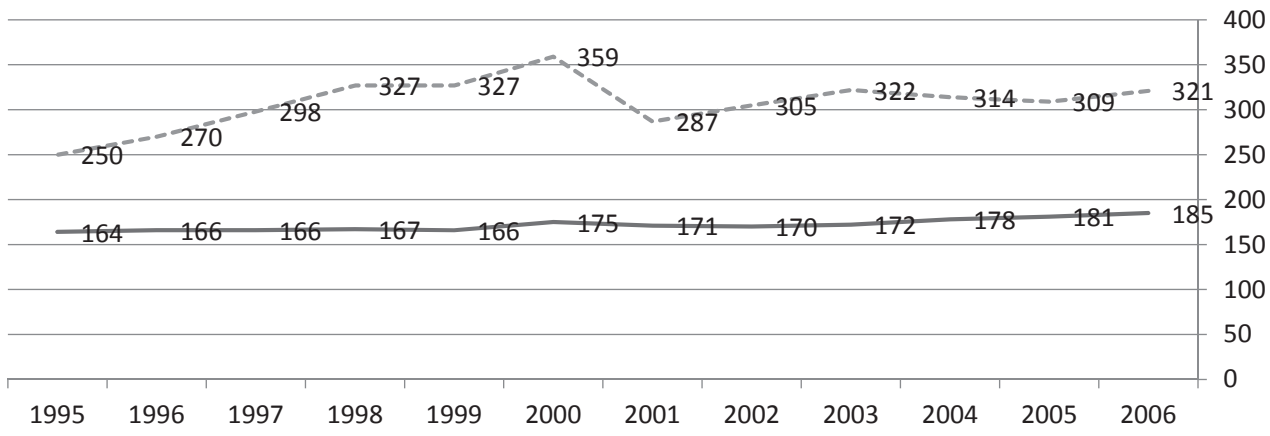

GDP Per Job in The ICT sector

GDP per Job- In Israel Economy

Figure 4: GDP per job in the ICT sector versus total economy GDP per job in 1995-2006 (NIS thousand) ${ }^{27}$

The data in Figure 4 clearly indicates two facts: First, the average GDP per worker in Israel's advanced industry is significantly higher than the average GDP per worker in the total Israeli economy. Second, from 1995 to 2006 (the year of the Second Lebanon War) the average GDP per worker in Israel's advanced industry rose (aside from the years 2001-2002, when this index receded due to the dot-com crisis). Therefore, considering that the number of those employed in Israel's advanced industry is gradually increasing (Figure 3) and considering that the GDP per worker in this industry is higher than the total average per worker in the Israeli economy (Figure 4), the total GDP of the advanced industry is gradually increasing and at the same time its contribution to Israel's total GDP is rising accordingly. Figure 5 below presents GDP data for Israel's advanced industry from the mid-1990s to 2013 versus data of Israel's total GDP.

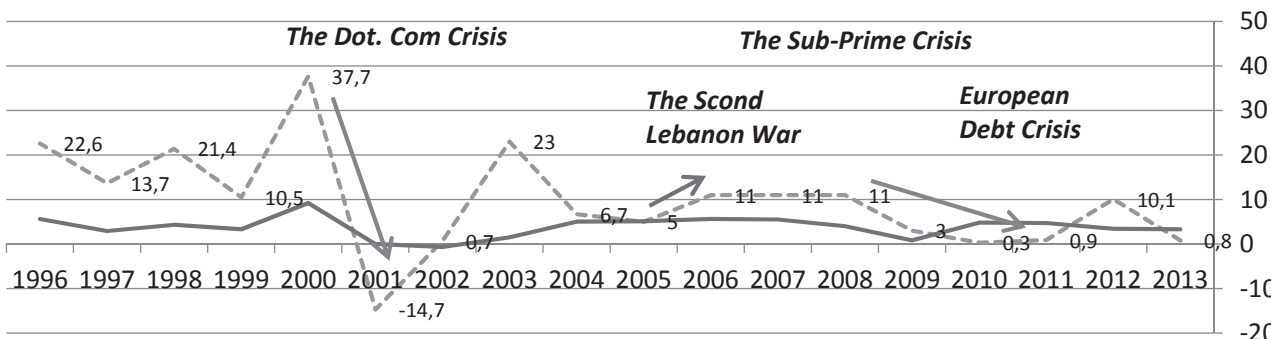

The Israeli ICT GDP sector (\%) — Total GDP- Israel Economy

Figure 5: Total GDP of the Israeli economy versus the Israeli ICT sector (annual \%) ${ }^{28}$

27 Source: Israeli Central Bureau of Statistics.

28 Source: Israeli Central Bureau of Statistics. 
The above figure clearly shows that the annual increase (in percentages) in the GDP of the advanced industry ${ }^{29}$ is much higher than the total Israeli GDP throughout the entire period portrayed. This fact indicates its conspicuous contribution to the increase in Israel's total GDP. In addition, this industry is obviously sensitive to external crises such as the global financial crises early on in this decade (the dot-com crisis) and in its later years (the subprime crisis and the European debt crisis), as during these periods GDP growth was only moderate, for instance in the later financial crises, ${ }^{30}$ or even diminished significantly, as in the earlier dot-com crisis. ${ }^{31}$

This leads to the question of how the Israeli hi-tech industry responds to internal stressors such as local wars. Will Israel's advanced industry remain stable and resilient in face of internal crises such as wars, unlike the effect of external stressors such as the global financial crises mentioned above, which lowered its growth rate? Will the indicators in this industry be affected by wars in the same way and to the same degree as Israel's total GDP and employment indicators, presented in Figures 1 and 2, mirroring the behavior of these indicators, or will they respond differently? Since Israel's advanced industry was only identified, defined, and developed in the 1990s, Figure 5 includes only the years 1996-2003, and as a result does not include four of the five wars surveyed in the current document. Therefore, the behavior of advanced industry indicators can only be examined during the Second Lebanon War (in 2006), when Israel's advanced industry was already in existence. The data presented in Figure 5 shows that, unlike the four previous wars (presented in Figure 1), where a diminishing of Israel's total GDP was evident during the war or in proximate years, the period of the Second Lebanon War is characterized by a growth in Israel's GDP (5.6\%). Moreover, the GDP indicators of the advanced industry continued to grow in 2006 (11\%), despite the war and unlike periods of global economic crisis when, as stated, the GDP of ICT industries decreased. Similar trends are also evident upon examining the export data of Israel's advanced industry versus the data of total Israeli exports for these years, as presented below in Figure 6.

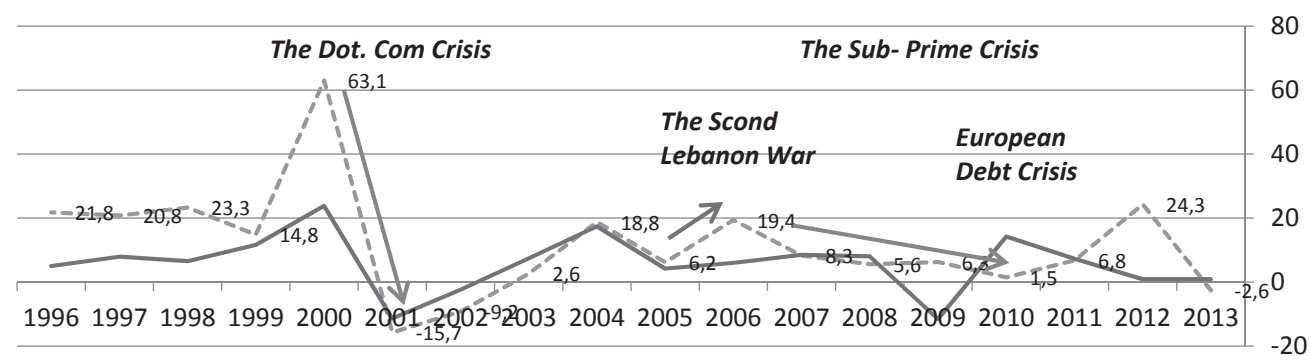

- - - The Israeli ICT Export (\%) — Total Export-Israel Economy

Figure 6: Total exports of the Israeli economy versus the Israeli ICT sector (annual \%) ${ }^{32}$

The data in Figure 6 indicates, on the one hand, a decrease in the exports of Israel's advanced industry early on in the decade (during the dot-com crisis) and a drop in the growth rate of this index towards the

29 This industry is portrayed in the figure as the ICT (Information and Communication Technology) industry.

${ }^{30}$ An increase of 3\% in 2009 (the subprime crisis) and a slight increase of $0.3 \%$ and $0.9 \%$ in 2010 and 2011 (respectively) with the evolvement of the European debt crisis.

31 A drop of $14.7 \%$ in 2001 in the midst of the dot-com crisis.

32 Source: Israeli Central Bureau of Statistics. 
end of the decade (during the subprime crisis and the European debt crisis), and on the other a conspicuous rise $(19.4 \%)$ in the growth rate of exports in this industry in the middle of the decade (during the Second Lebanon War). If so, why did the war in 2006 have a different effect on indicators of the Israeli economy than previous wars? In order to answer this question, Figure 7 below will examine the weight of Israel's advanced industry in proportion to the total Israeli economy during 1995-2006.

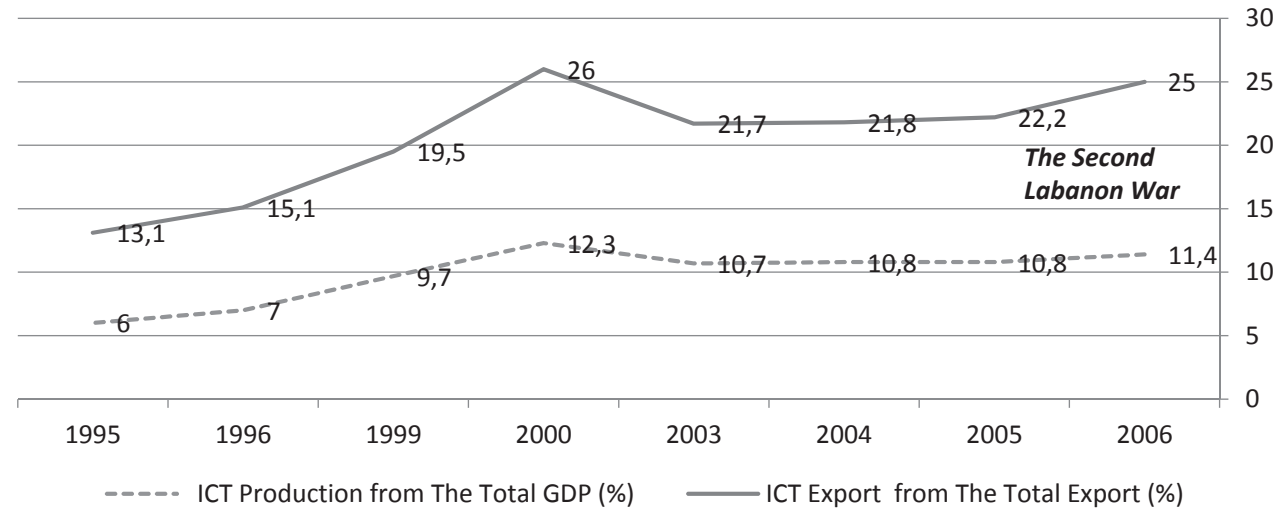

Figure 7: The relative weight of Israel's advanced industry indicators as a proportion of Israel's total economic indicators ${ }^{33}$

During the years 1995-2006 information technology industries developed considerably, in the world in general and in Israel in particular. The GDP of these industries in the Israeli economy showed impressive growth (by a factor of 2.8), ${ }^{34}$ exceeding Israel's total GDP growth rate. The data in Figure 7 above shows that the weight of the advanced industry GDP as a proportion of Israel's total GDP reached its highest point in 2000 and 2006, when it comprised about one quarter of the total GDP (26\% and 25\%, respectively). A similar trend is evident when examining the export data of advanced industry as a proportion of all Israeli exports (goods and services) during this period. These data as well show an increase in exports of the industry's products as a proportion of all exports, in 2000 and 2006 (12.3\% and $11.4 \%$, respectively).

Development of Israel's advanced industry, beginning from the mid-1990s, reached its peak in 2000, but halted and even receded somewhat with the US dot-com crisis in 2001, a crisis that strongly affected Israel's advanced industry. Since 2004 the indicators of advanced industry began to recover, approaching the pre-crisis peak by 2006 (the year of the Second Lebanon War). Hence, the data in Figure 7 may be said to lead to the same conclusion regarding the sensitivity of Israel's advanced industry to global financial crises on the one hand and the endurance and resilience of this industry in face of internal security crises such as war on the other. There seems to be a relationship between the development of Israel's advanced industry during 1995-2006 and the relative immunity of the Israeli economy during the Second Lebanon War (in 2006). Moreover, the increasing weight of this industry as a proportion of the Israeli economy in these years (as presented in Figure 7) may have contributed to the stability of the entire Israeli economy, so much so that it can be hypothesized that Israel's advanced industry constitutes an island of economic stability in times of war.

33 Source: Israeli Central Bureau of Statistics.

34 Mean annual increase of $10 \%$ (in 2005 prices), versus a mean increase of only $4 \%$ in the total GDP. 


\section{THE EFFECT OF ADVANCED INDUSTRY ON THE RESILIENCE OF THE ECONOMY IN TIMES OF WAR}

Figure 1 reviewed changes in Israel's GDP index during the different war periods and showed that the response of this index to the Second Lebanon War differed from its response to the other wars depicted. Figures 3-7 then presented the development of Israel's advanced industry by portraying the number of those employed in it, its GDP, its export rate, and the weight of these indices as a proportion of the total Israeli economy (respectively) from the mid-1990s to 2006 (the year of the Second Lebanon War). The trends presented in these figures clearly indicate a shift in the development of Israel's economy from the end of the First Lebanon War in the mid-1980s until the Second Lebanon War in the mid-2000s. This change was achieved, as stated, as a result of accelerated technological development, led by Israel's advanced industry. Is it possible, however, to establish the existence of a relationship between the growth of Israel's total GDP in 2006, notwithstanding the Second Lebanon War, and the development of Israel's advanced industry, which reached renewed heights in 2006? Is a modern economy based on advanced technology less sensitive to war? If so, which of the components of the advanced industry's GDP contributes to this immunity?

In order to answer such questions, we shall list below the GDP components that show volatility in times of war: As mentioned at the beginning of this document, one of the immediate effects of war is the drop in private consumption, as citizens of a country at war are not eager to visit shopping centers, entertainment and vacation complexes. It is indeed presumable that a modern developed economy with sophisticated military industries based on technology and innovations can provide its citizens with innovative defense technologies, ${ }^{35}$ thus increasing their sense of security and modifying the harm to private consumption, but this cannot completely eliminate the harmful effects. The additional GDP component of public consumption is also affected by the war since, as shown by the various studies mentioned at the beginning of this document, public consumption increases during hostilities, particularly in order to compensate for military spending. Therefore, it seems that with regard to consumption (both private and public) modern economies with their advanced technology will be affected in the same way as less developed economies (private consumption will decrease and public consumption increase).

Examination of the component of gross domestic investment in fixed assets ${ }^{36}$, one of the components of the total GDP, indicates its high sensitivity to global financial crises, as investments in the economy diminish in times of worldwide economic recession. In Israel, gross domestic investments decreased both during the global dot-com crisis in 2001-2003 (-3\%, -10.9\%, and $-4.9 \%$, respectively) and during the subprime crisis in 2009 (-8.8\%). However, this component appears to be less sensitive to war, as evident from its $6.4 \%$ growth in 2006. Nonetheless, examination of gross domestic investment data for the year preceding the Second Lebanon War (13.2\% in 2005) on the one hand and for the year after the war (12.1\% in 2007) on the other ${ }^{37}$ shows relatively moderate growth of this GDP component in times of uncertainty compared to peaceful years. Examination of the investment component in advanced industry shows that this industry as well is not immune to negative effects in times of war. In times of peace a country with a reputation for technological innovation and well-developed entrepreneurship constitutes an attractive investment destina-

35 Such as the Iron Dome system, extensively used by Israel in the recent operation in Gaza (July-August 2014).

36 This component includes investments in fixed assets by businesses, the government sector, and non-profit organizations. Expenditures include the purchase of sustainable assets (excluding land and mineral deposits) for civil use, construction works in process, large scale renovations, paving roads and other infrastructure works, and expenditures for preparation of land and groves. It also includes investment in intangible assets (mainly expenditures for acquiring and self-production of software and mineral exploration expenditures- oil and gas). Government sector expenditures for construction and military equipment are not included.

37 Source: Israeli Central Bureau of Statistics. 
tion for foreign investors and entrepreneurs, however military activity puts this activity on hold until things calm down. Israeli hi-tech companies are financed mainly by venture capital funds and private equity, then examination of the total capital of these sources of investment in Israeli hi-tech companies in 2006 indicates a sharp drop of nearly $\$ 1.5$ billion (-50\%) compared to the year before the war, as evident from the data in Table 1:

Table 1

Capital raised by VC \& PE funds 2002 - 2012 ( $\$ \mathrm{~m})$ by vintage year ${ }^{38}$

\begin{tabular}{|l|c|c|c|c|c|c|c|c|c|c|c|}
\hline & 2002 & 2003 & 2004 & 2005 & 2006 & 2007 & 2008 & 2009 & 2010 & 2011 & 2012 \\
\hline Venture Capital & 69 & 70 & 582 & 1,531 & 835 & 935 & 1,115 & 230 & 0 & 865 & 617 \\
\hline Private Equity & 160 & 47 & 996 & 1,295 & 563 & 540 & 484 & 1,335 & 98 & 650 & 1,175 \\
\hline All Funds & 229 & 117 & 1,578 & 2,826 & 1,398 & 1,475 & 1,599 & 1,565 & 98 & 1,515 & 1,795 \\
\hline
\end{tabular}

Accordingly, it seems that the claim concerning the ability of a technologically developed economy to withstand the effects of war cannot be explained by allegedly unique characteristics of the production and investment components of advanced industry which seemingly contribute to the immunity of the economy's total GDP. Hence, it remains to examine the effect of the export component of advanced industry, which is one of the total GDP components.

Unlike the output of sustainable products and raw materials, characteristic of traditional or mixed industries, the output of advanced industry is characterized by the production of information and the development of advanced products. These information and products easily fill the demand of the domestic market, particularly in the case of a small country such as Israel, and are rapidly diverted to the rest of the world. The globalization of hi-tech products and services is particularly efficient and rapid. Thus, the export of Israel's advanced industry is constantly growing, with the exception of times of financial crisis (as presented in Figure 6). In such times, the demand for products and services, including the products and services of advanced industry (as in the dot-com crisis and the subprime crisis) diminishes, and therefore the global demand for the output of Israel's advanced industry diminishes as well. However, so long as there is no decrease in the global demand for the products and services of this industry, Israel's advanced industry shall remain a conspicuous and relevant source of trade, since foreign companies that require certain technological knowledge, services, or products in order to develop their business shall continue to do business with the well-developed Israeli economy so long as this economy produces the necessary knowledge, notwithstanding the fact that this economy is in a state of war (as evident in 2006), unless the companies have other alternatives for purchasing the knowledge they need. A technological leader such as Israel continues to produce and export technological products in times of war as well, such that exports by its advanced industry, constituting a not insignificant part ${ }^{39}$ of Israel's total exports, are only slightly affected (if at all) by the country's state of war, moderating the overall harm to Israeli exports. Therefore, the claim concerning the relationship between technological development and economic resilience, with its particular salience in times of war, is based on the strength and resilience of advanced industry exports. The resilience of this component in face of security threats increases the more technologically developed the local economy and the greater the impact of advanced technology.

38 http://www.ivc-online.com/upload/IVC2014/learnmore/pdfs/View_Sample_2013.pdf Source: IVC Research Center.

39 In 2006 advanced industry exports constituted some $25 \%$ of Israel's total experts (as presented in Figure 6). 


\section{CONCLUSION}

This study explored the relationship between the resilience of the local economy and the strength of advanced industry within this economy. The relationship was examined in the case of a real security crisis such as that experienced by Israel in 2006 during the Second Lebanon War. The data presented in the article leads to the conclusion that the development of Israel's economy throughout the 2000 s is directly associated with the development of its advanced industry. This advanced industry is export-oriented and therefore contributes significantly to the Israeli economy's total GDP, a contribution that increases with the weight of this industry. This contribution derives to a large degree from the conspicuous growth in the number of those employed in Israel's advanced industry (Figure 3), which has a relatively high average capacity compared to other industries (Figure 4) and therefore contributes significantly to Israel's total GDP.

Figure 5 presented the increased growth of Israel's GDP in 2006 despite the Second Lebanon War. This trend differed from those characteristic of this index in previous wars, when the GDP growth rate decreased (aside from the Six Day War in 1967, which is a special case analyzed and explained above). Examination of Israel's total GDP in that year versus the GDP of advanced industry shows that the increase in the advanced industry GDP was about double that of Israel's total GDP (11\% versus 5.6\%, respectively). The attempt to analyze changes in GDP components of advanced industry during the Second Lebanon War in order to learn of its real contribution to Israel's total GDP shows that this contribution is mainly based on the industry's exports. Israel's advanced industry is mainly oriented at export, a fact representing the major attractiveness of its products all over the world as a matter of routine as well as in wartime. Figure 6 presents the rise in Israel's advanced industry export index during the 2000s, attesting to the conspicuous increase in exports in advanced industry (19.4\%) in 2006 despite the Second Lebanon War. This is even more impressive in comparison to the relatively moderate increase in Israel's total exports in that year (only 6\%). As stated, the greater the relative weight of advanced industry as a proportion of all Israeli industry, the greater its effect on domestic economic indices. Thus, in 2006 advanced industry seems to have had a not insignificant effect on Israel's economic indicators, as the industry's exports constituted 25\%(!) of Israel's total exports (Figure 7). In addition, the data in Figures 3-6 indicate the high sensitivity of Israel's advanced industry to global financial crises, as evident from the employment, GDP, and export indicators of this industry during the dot-com crisis in the early 2000s and during the subprime crisis and the European debt crisis towards the end of the first decade of the 2000s and at the beginning of the second decade (respectively).

In conclusion of this document, even if it failed to bring unequivocal proof of the contribution of Israel's advanced industry to the immunity of the local economy in general and in wartime in particular, it nonetheless presented data capable of attesting to this contribution and portraying it as highly likely. Although this study is about the economy in wartime, and peaceful existence is obviously much more desirable, history regretfully teaches us that wars are a not infrequent occurrence among human beings. Accordingly, this relationship between the strength of Israel's advanced industry and the immunity of the local economy should be further studied also in light of future wars, if and when they occur in the area. Nonetheless, it is already possible to identify advanced industry as a primary intervening variable in the relationship between war and the fluctuating economic indicators of affected countries. 


\section{REFERENCES}

Avnimelech, G. ,Teubal , M. (2004). Venture capital start-up co-evolution and the emergence and development of Israel's new high tech cluster. Economics of Innovation and New Technology, 1, 33-60.

Baker, D. (2007). The economic impact of the Iraq War and higher military spending, Centre for Economic and Policy Research (CEPR), viewed 1 October 2011. http://www.cepr.net/documents/publications/ military spending_2007_05.pdf.

Boskin, M. J., Lawrence, J. L. (1990). Post-war economic growth in the group-of-five countries: A new analysis. National Bureau of Economic Research (NBER) Working Paper No. 3521. Cambridge.

Bard, M. G. (2007). Will Israel Survive?. USA: Macmillan Publish. Chapter 9, 151-164.

Bloch, K. (1941). Japanese War economy, Annals of the American Academy of Political and Social Science, $215,17-23$.

Breznitz, D. (2006). Innovation and the State--Development Strategies for High Technology Industries in a World of Fragmented Production: Israel, Ireland, and Taiwan. Oxford: Oxford Publishing.

Castles, F. G. (1999). Decentralization and the post -war political economy. European Journal of Political Research, 36 (1),27-53.

Cohen, E. (2009). The Israeli Hi-Tech Industry: No Thought for the Future. Jerusalem: Carmel Publishing House. (Hebrew)

Collie, P. (1999). On the economic consequences of civil war. Oxford Economic Papers, 51 (1),168-183.

De Fontenay, C., Carmel, E. (2001). Israel's Silicon Wadi: The Forces Behind Cluster Formation. Stanford Institute for Economic Policy Research. Stanford University.

Edelstein, M. (2000). War and the American economy in the twentieth century. In: Gallma, R. E. Engerman, S. L. (Editors). The Cambridge Economic History of the United States. Cambridge University Press. 329$346 .$.

Gabbay, Y. (2009). Political Economy- The Gap between Perception and Reality. Hakibbutz Hameuhad Publishing House. (Hebrew).

Hancock, W. K. (1949). British War Economy. London: His Majesty's Stationery Office.

Higgs, R. (2006). Depression, War, and Cold War: Studies in Political Economy. Oxford University Press. New York.

Institute for Economics \& Peace (2011). Economic Consequences of War on the U.S Economy. SydneyNew York- Washington D.C.

Kaldor, N. (1946). The German War economy. The Review of Economic Studies, 13 (1), 33-52 .

Karsh, E. (2002). Israel War. Commentary, 113 (4), 23-28.

Lee E. O. (1997). The macroeconomic effects of war finance in the United States: World War II and the Korean War. The American Economic Review, 87 (1), 23-40

Lebrecht, H (2003). Israel's wretched economy is result of war policy. People's Weekly World, 17 (34), 6-20.

Neuman, S., Shenhav, Y. (1977). Short term impact of war economy on the insurance industry in Israel. Journal of Risk and Insurance, 44 (1),32-55

Overy, R. J. (1994). War and Economy in the Third Reich, Clarendon Press.

Pauer, E. (2002). Japans War Economy. Rutledge Studies in the Growth Economies of Asia, 21, 22-35

Rawlings, L. (2007). Ancient Greeks at War. Manchester University Press.

Riddell, T. (1970). The economic effects of the war in Vietnam. Review of Radical Political Economics, 2 (41), 63-82.

Senor, D., Singler, S. (2012). Innovation and Technology in the World: Evolution of a New Industry. A Genealogical Approach. Stanford Business Book. 
Stiglitz, J., Blimes, L. (2011) Estimating the costs of war: Methodological issues, with applications to Iraq and Afghanistan. Chapter 13, Oxford Handbook of the Economics of Peace and Conflict. Oxford University Press. New York.

Stubbs, R. (1999). War and economic development: export-oriented industrialization in East and Southeast Asia. Comparative politics, 31 (3), 355-337.

Warren, R. (1940). War financing and its economic effects. Proceedings of the Academy of Political Science, 18 (4), 69-77.

Wolf, F. B. (1940). Economy in war time. In: Waller, Willard (Ed.), War in the Twentieth Century.363-408. New York, NY: Random House.

Yang, B., Lester, D. (1994). The effect of war on the economy. Atlantic Economic Journal. Drexel University. 22 (3), 81-95. 